\title{
Factors Affecting the Imaging Preference of Acute Pancreatitis Patients in the Emergency Department: A Retrospective Study on 63 Cases
}

\author{
Acil Serviste Akut Pankreatit Hastalarının Görüntüleme Istemlerini Etkileyen Faktörler: 63 \\ Olguluk Retrospektif Çalışma
}

\author{
(D) Serhat ÖRÜN \\ Tekirdağ Namık Kemal University Faculty of Medicine, Department of Emergency Medicine, Tekirdağ, Turkey
}

\begin{abstract}
Aim: Acute pancreatitis is an inflammatory disease in which the pancreas is affected at different levels. It is often reversible. The diagnosis of pancreatitis is made by evaluating the anamnesis, physical examination, laboratory and radiological examinations together. Usually ultrasonography (USG) and contrast-enhanced abdominal tomography (CT) are needed for diagnosis in emergency services. The aim of this study is to contribute to the use of imaging techniques used for the diagnosis of acute pancreatitis patients in the emergency department with the correct indications.

Materials and Methods: Our study is retrospective. All patients over the age of 18 years who were admitted to our emergency department between 01.01.2019 and 01.01.2020 and diagnosed with acute pancreatitis were included in the study. The demographic characteristics, laboratory findings, imaging procedures and imaging findings of the patients were determined by examining the files of the patients included in the study.

Results: A total of 63 patients were included in the study. The mean age of the patients was $59.69 \pm 17.33$ years and 38 (60.3\%) of them were women. Of these 63 patients, 54 (85.7\%) had abdominal USG and 37 (58.7\%) had abdominal CT imaging with contrast. The mean amylase value of the cases was $958.01 \pm 1051.69$ and the mean lipase value was 1051.28 \pm 1340.92 . There was no statistical relationship between Ranson score and lipase level $(p=0.681)$. When the Ranson scores of the patients with biliary and non-biliary pancreatitis were compared, there was not a statistically significant difference $(p=0.844)$.

Conclusion: We think that USG imaging should be used in all patients for acute pancreatitis in the emergency department, its main indication is for gallbladder and intra/extra hepatic biliary tract pathologies. In addition, we think that the indications for contrast-enhanced abdominal CT imaging should be clarified, except for the exclusion of severe acute pancreatitis and other possible emergency pathologies.
\end{abstract}

Keywords: Emergency service, acute pancreatitis, imaging, CT, USG

ÖZ

Amaç: Akut pankreatit, pankreasın farklı seviyelerde etkilendiği enflamatuvar bir durumdur. Tanısı için anamnez, fizik muayene, laboratuvar ve radyolojik tetkiklerin birlikte değerlendirilmesi gerekmektedir. Acil servislerde görüntüleme olarak sıklıkla ultrasonografi (USG) ve kontrastlı batın bilgisayarlı tomografiye (BT) ihtiyaç duyulmaktadır. Bu çalışmanın amacı acil serviste akut pankreatit hastalarının tanısı için kullanılan görüntüleme tekniklerinin doğru endikasyonlarla kullanımına katkı sağlamaktır.

Gereç ve Yöntem: Çalışmamız retrospektif bir çalışma olup çalışmaya acil servisimize 01.01.2019 ile 01.01.2020 tarihleri arasında başvuran, 18 yaşından büyük ve akut pankreatit tanısı alan tüm hastalar dahil edildi. Çalışmaya dahil edilen hastaların dosyaları incelenerek hastaların demografik özellikleri, laboratuvar bulguları, yapılan görüntüleme işlemleri ve elde edilen görüntüleme bulguları belirlendi.

Address for Correspondence: Serhat ÖRÜN MD, Tekirdağ Namık Kemal University Faculty of Medicine, Department of Emergency Medicine, Tekirdağ, Turkey Phone: +90 5335136546 E-mail: serhatorun@gmail.com ORCID ID: orcid.org/0000-0001-5879-7858

Received: 06.05.2021 Accepted: 27.08.2021

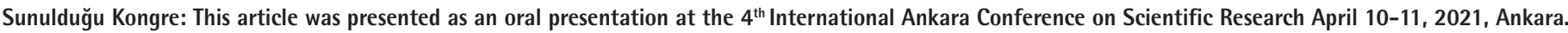

${ }^{\circ}$ Copyright 2021 by the Tekirdağ Namık Kemal University Faculty of Medicine / Namık Kemal Medical Journal published by Galenos Publishing House. 


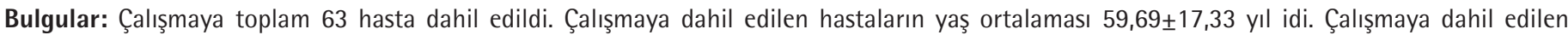
hastalardan 38'i $(\% 60,3)$ kadındı. Bu 63 hastadan $54(\% 85,7)$ tanesine batın USG, $37(\% 58,7)$ tanesine kontrastlı batın BT görüntüleme yapıldı.

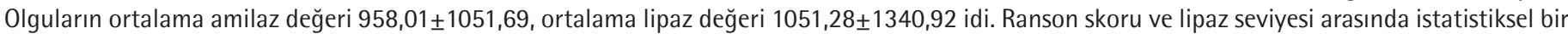
ilişki bulunamadı $(p=0,681)$. Bilier ve non-bilier pankreatitli olguların ranson skoru karşılaştırıldığında istatistiksel olarak anlamlı bir fark bulunamadı $(\mathrm{p}=0,844)$.

Sonuç: Acil serviste akut pankreatit için USG görüntülemenin tüm hastalarda kullanılmasının gerekli olduğunu, bunun asıl endikasyonunun safra kesesi ve intra/ekstra hepatik safra yolu patolojilerine yönelik olduğunu, kontrastlı batın BT görüntülemede ise şiddetli akut pankreatit ve olası diğer acil patolojilerin dışlanması haricinde endikasyonlarının netleştirilmesi gerektiğini düşünmekteyiz.

Anahtar Kelimeler: Acil servis, akut pankreatit, görüntüleme, BT, USG

\section{INTRODUCTION}

Rapid hospitalization or discharge of the patients whose diagnosis is confirmed in the emergency department is important for the rapid and effective management of the crowded patient load in the emergency department. One of the biggest obstacles in front of this situation is the additional imaging tests requested by the relevant departments in the patient group whose diagnosis is confirmed. Patients with acute pancreatitis are also included in the group in which this situation is frequently experienced in emergency services.

Acute pancreatitis is an inflammatory disease in which the pancreas is directly affected by the enzymes it secretes. This inflammation can affect the pancreas as well as neighboring tissues and organs. The mortality and morbidity of acute pancreatitis is high, and this rate may increase to $25 \%$, especially in its severe form. The clinical picture varies from mild form, which responds to medical treatment in a short time, to severe form accompanied by systemic findings, sepsis and multi-organ failure. For the diagnosis of the disease, anamnesis, physical examination, laboratory and radiological examinations should be evaluated together ${ }^{1,2}$. One or several of ultrasonography (USG), contrast-enhanced abdominal computed tomography (CT) or magnetic resonance cholangiopancreatography imaging is preferred in emergency services.

Our aim in doing this study is to contribute to the use of imaging techniques with the right indications by creating awareness about the effectiveness of imaging techniques used for the diagnosis of acute pancreatitis patients in the emergency department.

\section{MATERIALS AND METHODS}

Our study is a retrospective study. Before starting the study, permission was obtained from the Non-Invasive Studies Ethics Committee of Tekirdağ Namık Kemal University Faculty of Medicine (2021.52.02.15).

All patients older than 18 years of age and clinically diagnosed with acute pancreatitis, who applied to our emergency department between 01.01.2019 and 01.01.2020, were included in the study. The files of the patients included in the study were examined and their demographic characteristics, laboratory findings, USG, CT and other imaging examinations and the findings obtained from these examinations were determined. Patients whose necessary information could not be reached were excluded from the study even if they were diagnosed with acute pancreatitis and were older than 18 years. Afterwards, all the obtained data were recorded in the database prepared in the statistical program named Statistical Package for the Social Sciences 18 and analyzed.

\section{Statistical Analysis}

Descriptive statistics for categorical variables were expressed as numbers ( $\mathrm{n}$ ) and percentage (\%). The chi-square test was used to compare data between groups. The normal distribution of continuous variables was evaluated using the KolmogorovSmirnov test. The Mann-Whitney $U$ test was used for group comparisons. A $p$ value of $<0.05$ was considered statistically significant.

\section{RESULTS}

A total of 63 patients were included in the study. The mean age of the patients included in the study was $59.69 \pm 17.33$ years. Of the patients included in the study, $38(60.3 \%)$ were female. In the emergency department, $54(85.7 \%)$ of these 63 patients underwent abdominal USG and 37 (58.7\%) underwent contrast-enhanced abdominal CT imaging. Blood samples were taken from all patients for hemogram and biochemistry tests. The mean amylase value of the cases was $958.01 \pm 1051.69$, and the mean lipase value was $1051.28 \pm 1340.92$. In 60 (95.3\%) of the subjects included in the study, the lipase value was above $60 \mathrm{U} / \mathrm{L}$. Demographic characteristics and laboratory values of the cases included in the study are presented in Table 1.

When the cases were evaluated in terms of the Ranson criteria score at the time of first admission, it was determined that $21(33.3 \%)$ patients scored 0, $24(38.1 \%)$ patients 1 point, $12(19 \%)$ patients 2 points, $6(9.5 \%)$ patients 3 points. No statistical relationship was found between Ranson score and lipase level $(p=0.681)$.

Gallstones were detected in $33(61.1 \%)$ of the 54 patients who underwent USG imaging, sludge in $4(7.4 \%)$ patients, 
intrahepatic bile duct dilatation in 5 (9.3\%), choledochal dilatation or normal appearance in 21 (38.9\%). Information was shared for $3(5.6 \%)$ of them about whether an evaluation could be made about the pancreas. In 48 (88.9\%) patients who underwent USG, the imaging procedure was suboptimal due to intestinal gas, and it was recommended to confirm with abdominal CT if necessary (Table 2).

Thirty-three (52.4\%) of the cases were evaluated as biliary pancreatitis and $30(47.6 \%)$ as non-biliary pancreatitis. When

Table 1. Demographic characteristics and laboratory values of the cases

\begin{tabular}{|c|c|}
\hline & $\begin{array}{l}\text { n }(\%) \\
\text { Mean } \pm \text { standard deviation }\end{array}$ \\
\hline Age & $59.69 \pm 17.33$ \\
\hline \multicolumn{2}{|l|}{ Gender } \\
\hline Female & $38(60.3 \%)$ \\
\hline Male & $25(39.7 \%)$ \\
\hline USG & $54(85.7 \%)$ \\
\hline $\mathrm{CT}$ & 37 (58.7\%) \\
\hline Biliary pancreatitis & $33(52.4 \%)$ \\
\hline Amylase & $958.01 \pm 1051.69$ \\
\hline Lipase & $1051.28 \pm 1340.92$ \\
\hline AST & $102.52 \pm 121.89$ \\
\hline ALT & $109.15 \pm 138.43$ \\
\hline ALP & $146.00 \pm 88.40$ \\
\hline GGT & $224.16 \pm 331.45$ \\
\hline $\mathrm{Hg}$ & $12.84 \pm 2.06$ \\
\hline HTc & $38.92 \pm 5.54$ \\
\hline WBC & $10.61 \pm 3.85$ \\
\hline Plt & $248.60 \pm 111.16$ \\
\hline \multicolumn{2}{|c|}{$\begin{array}{l}\text { USG: Ultrasonography, CT: Computed tomography, AST: Aspartate aminotransferase } \\
\text { ALT: Alanine aminotransferase, ALP: Alkaline phosphatase, GGT: Gamma glutamyl } \\
\text { transferase, Hg: Hemoglobin, HTC: Hematocrit, WBC: White blood cell, Plt: Platelet }\end{array}$} \\
\hline
\end{tabular}

Table 2. Findings obtained in patients undergoing ultrasonography

\begin{tabular}{|l|l|}
\hline Findings & $\mathbf{n}(\mathbf{\%})$ \\
\hline Gall bladder operated & $8(14.8 \%)$ \\
\hline Gallstone & $33(61.1 \%)$ \\
\hline Inside the bladder & $21(38.9 \%)$ \\
\hline Bile ductus & $10(18.5 \%)$ \\
\hline Choledochus & $2(3.7 \%)$ \\
\hline Sludge & $4(7.4 \%)$ \\
\hline Pericholecystic fluid & $1(1.9 \%)$ \\
\hline Peripancreatic fluid & $2(3.7 \%)$ \\
\hline Intrahepatic bile duct dilatation & $5(9.3 \%)$ \\
\hline Suboptimal imaging due to intestinal gas & $48(88.9 \%)$ \\
\hline Evaluation of the choledochus & $21(38.9 \%)$ \\
\hline Evaluation of the pancreas & $3(5.6 \%)$ \\
\hline
\end{tabular}

the Ranson scores of the biliary and non-biliary pancreatitis cases were compared, no statistically significant difference was found $(p=0.844)$.

In the official radiology reports of 37 patients who underwent contrast-enhanced abdominal CT imaging, it was determined that stones were detected in $10(27 \%)$, gall bladder was operated in 5 (13.5\%), sludge was found in 1 (2.7\%), 5 (13.5\%) of them had dilatation in the intrahepatic bile ducts, 5 (13.5\%) had dilatation in the choledoch, pericholecystic fluid was detected in 7 (18.9\%), fluid in the peripancreatic area was detected in $13(35.1 \%), 14(37.8 \%)$ had inflammation in the pancreas, and $3(8.1 \%)$ had necrosis in the pancreas (Table 3$)$.

\section{DISCUSSION}

Imaging is very important in the diagnosis and prognosis of acute pancreatitis. Considering the possibilities and conditions of the emergency services, it is still not clear in some clinical situations that which of these imagings should be done in the emergency room and which ones should be done in the relevant departments.

Gallstones and excessive alcohol use are involved in the etiology of $70-80 \%$ of acute pancreatitis cases ${ }^{3}$. Indeed, it is important to distinguish these etiologies due to differences in patient management. The sensitivity and specificity of USG in the detection of gallstones is over $95 \%{ }^{4-7}$. In the review of Greenberg et al. ${ }^{8}$, with high evidence and strong recommendation, it is stated that USG should be performed initially in all patients with acute pancreatitis to determine whether the patient has gallstones and/or stones in the common bile duct or to evaluate the biliary tract. In the study of Yardan et al. ${ }^{9}$, it was determined that abdominal USG was performed on all patients in the emergency department and 12 (19.7\%) of these patients were compatible with pancreatitis, while 29 (47.5\%) were not.

\section{Table 3. Findings obtained in patients who underwent CT}

\begin{tabular}{|l|l|}
\hline Findings & $\mathbf{n}(\%)$ \\
\hline Increase in gallbladder wall thickness & $3(8.1 \%)$ \\
\hline Gall bladder operated & $5(13.5 \%)$ \\
\hline Gallstone & $10(27 \%)$ \\
\hline Inside the bladder & $5(13.5 \%)$ \\
\hline Bile ductus & $4(10.8 \%)$ \\
\hline Choledochus & $1(2.7 \%)$ \\
\hline Sludge & $1(2.7 \%)$ \\
\hline Intrahepatic bile duct dilatation & $5(13.5 \%)$ \\
\hline Choledochus duct dilatation & $5(13.5 \%)$ \\
\hline Pericholecystic fluid & $7(18.9 \%)$ \\
\hline Peripancreatic fluid & $13(35.1 \%)$ \\
\hline Inflammation & $14(37.8 \%)$ \\
\hline Necrosis & $3(8.1 \%)$ \\
\hline CT: Computed tomography & \\
\hline
\end{tabular}


In the study conducted by Karaca and 0ktay ${ }^{10}$ it was determined that abdominal USG was performed in all cases in the emergency department. It was revealed that the USG findings were compatible with pancreatitis in $30(25.9 \%)$ patients, not compatible with pancreatitis in $61(52.6 \%)$ patients, and also resulted in insufficient USG interpretation due to intense intestinal gas in $25(21.6 \%)$ patients ${ }^{10}$. In our study, abdominal USG imaging was performed in 54 (85.7\%) of 63 patients with acute pancreatitis detected in the emergency department, and it was determined that pancreatic evaluation could be performed in $3(5.6 \%)$ patients. However, it was also stated that imaging was suboptimal due to intestinal gas in 48 (88.9\%) patients who underwent USG. The effectiveness of abdominal USG may be restricted by reasons such as intestinal gas and obesity in pancreatic imaging. In fact, it can be thought that abdominal USG request in the emergency department slows down patient management in this patient group. However, we think that abdominal USG should be applied to all patients with acute pancreatitis in the emergency department because of its contribution to the management of the patient in acute pancreatitis and its contribution to the exclusion of surgical or other causes of acute abdominal pain. In addition, we think that it should be remembered that emergency USG imaging creates a greater indication for the differentiation of biliary and non-biliary pancreatitis in these patients. USG was not performed in the emergency department for all of the cases in our study. We attribute this situation to the fact that some of the patients who applied to our emergency department were evaluated by the relevant polyclinic during the day and applied to our emergency department after the USG procedure.

The increase in the accessibility and usability of CT creates a trend for physicians to refer to this examination more frequently for research purposes. An advanced CT scan is the most effective method for diagnosing acute pancreatitis and pancreatic necrosis, with typical features on cross-sectional imaging such as pancreatic enlargement, pancreatic edema, uneven density, peripancreatic fat shift, and fluid collection". In their review, Waller et al. ${ }^{12}$ stated that CT was not sensitive for early diagnosis of pancreatitis, since CT imaging might not show findings in patients with mild acute pancreatitis. Moreover, some studies have reported that although abdominal CT can identify pancreatitis in the early phase of the disease course, it will not contribute to the diagnostic sensitivity and may be negative if performed too early ${ }^{13-15}$. However, it is accepted that CT imaging can be used if the possibility of necrotizing pancreatitis is suspected in severe cases $^{8,11,16,17}$. As a result of all these, the use of $\mathrm{CT}$ remains limited unless there are other conditions that should be evaluated in the differential diagnosis of acute pancreatitis cases in emergency services ${ }^{8}$

In the study conducted by Yardan et al. ${ }^{9}, 52(85.2 \%)$ of the patients with acute pancreatitis in the emergency department underwent abdominal $\mathrm{CT}$, and $32(61.5 \%)$ of the patients who were performed abdominal CT had mild clinical manifestations, $20(38.5 \%)$ had severe. In the study conducted by Karaca and Oktay ${ }^{10}$, it was determined that $9(7.8 \%)$ patients had Ranson criteria score of 3 and above, and the number of patients who had abdominal CT was 38 (32.8\% of all patients). Moreover, in this study, the importance of determining the indications for abdominal CT in the emergency department and the criteria for requesting tomography in the early period was emphasized.

In their study, Munoz-Bongrand et al. ${ }^{18}$ performed contrastenhanced abdominal CT scans of 102 patients with acute pancreatitis during their hospitalization and on the $7^{\text {th }}$ day after hospitalization. They suggested that early CT in patients with a Ranson score of 2 or less was not very valuable in demonstrating acute pancreatitis, and that CT should not be routinely ordered in the late period, but should be performed to see necrosis and other complications in the occurrence of clinical and biological deterioration ${ }^{10,18}$. In our study, contrastenhanced abdominal CT imaging was performed in 37 (58.7\%) of 63 patients with acute pancreatitis and in patients with acute pancreatitis who underwent $\mathrm{CT}$, findings related to fluid in the peripancreatic area, inflammation and necrosis in the pancreas were obtained. However, when the patients included in our study were evaluated according to the Ranson scores, it was found that the rate of patients who underwent CT was considerably higher than the severe pancreatitis group according to the scoring systems, in accordance with the literature. Causes of this condition may include exclusion of other possible causes of abdominal pain in the emergency department. However, it is a reality for all emergency services that it can also be performed upon the request of the relevant clinic when the patient is admitted to a clinic. It is known that CT has a critical importance in the staging of acute pancreatitis, evaluation of its complications and interventional treatment. Of course, we accept the necessity of performing abdominal CT in severe acute pancreatitis cases in the emergency department. In addition, it can also be preferred in the differential diagnosis to rule out other possible diagnoses. However, we think that its use in emergency services based on indications supported by strong evidence and recommendation may be more beneficial in terms of patient victimization, sustainability of emergency functioning and cost.

\section{Study Limitations}

The small sample size and retrospective nature of the study were the most important limitations. In addition, despite being detected in abdominal CTs, there was also the possibility that the findings, which were detected with USG and stated in the report, were not re-expressed in the CT reports, in order to report the CTs faster for speeding up the emergency room management in emergency conditions. 


\section{CONCLUSION}

In conclusion, we think that it is necessary to use USG imaging for acute pancreatitis in the emergency department in all patients, the main indication is for gallbladder and intra/extra hepatic bile duct pathologies, and the emergency indications should be clarified in contrast-enhanced abdominal CT imaging, except for the exclusion of severe acute pancreatitis and possible other emergency pathologies.

\section{Ethics}

Ethics Committee Approval: Ethic permission was obtained from the Non-Invasive Studies Ethics Committee of Tekirdağ Namık Kemal University Faculty of Medicine (2021.52.02.15).

Informed Consent: Retrospective study.

Peer-review: Externally peer-reviewed.

Financial Disclosure: The author declared that this study received no financial support.

\section{References}

1. Carroll JK, Herrick B, Gipson T, Lee SP. Acute pancreatitis: diagnosis, prognosis, and treatment. Am Fam Physician. 2007;75:1513-20.

2. Maher MM, Lucey BC, Gervais DA, Mueller PR. Acute pancreatitis: the role of imaging and interventional radiology. Cardiovasc Intervent Radiol. 2004;27:208-25.

3. Bernicker E. Internal Medicine: Cecil Textbook of Medicine. JAMA 1998;280:1368. doi: 10.1001/jama.280.15.1368-JBK1021-3-1

4. Bar-Meir S. Gallstones: prevalence, diagnosis and treatment. Isr Med Assoc J. $2001 ; 3: 111-3$

5. Portincasa P, Moschetta A, Petruzzelli M, Palasciano G, Di Ciaula A, Pezzolla A. Gallstone disease: Symptoms and diagnosis of gallbladder stones. Best Pract Res Clin Gastroenterol. 2006;20:1017-29.
6. Benarroch-Gampel J, Boyd CA, Sheffield KM, Townsend CM Jr, Riall TS. Overuse of CT in patients with complicated gallstone disease. J Am Coll Surg. 2011;213:524-30.

7. Ou ZB, Li SW, Liu CA, Tu B, Wu CX, Ding X, et al. Prevention of common bile duct injury during laparoscopic cholecystectomy. Hepatobiliary Pancreat Dis Int. 2009;8:414-7.

8. Greenberg JA, Hsu J, Bawazeer M, Marshall J, Friedrich JO, Nathens A, et al. Clinical practice guideline: management of acute pancreatitis. Can J Surg. 2016;59:128-40.

9. Yardan T, Genc S, Baydın A, Nural MS, Aydın M, Aygun D. Acil Serviste Akut Pankreatit Tanısı Alan Hastaların Değerlendirilmesi. Fırat Tıp Dergisi. 2009;14:124-8.

10. Karaca E, Oktay C. Travma Dışı Akut Pankreatit Olgularında Prognostik Kriterlerin Sonuç Üzerine Etkisi. Turk J Emerg Med. 2008;8:18-25.

11. Zheng Z, Ding YX, Qu YX, Cao F, Li F. A narrative review of acute pancreatitis and its diagnosis, pathogenetic mechanism, and management. Ann Transl Med. 2021;9:69.

12. Waller A, Long B, Koyfman A, Gottlieb M. Acute Pancreatitis: Updates for Emergency Clinicians. J Emerg Med. 2018;55:769-79.

13. Mortele KJ, Ip IK, Wu BU, Conwell DL, Banks PA, Khorasani R. Acute pancreatitis: imaging utilization practices in an urban teaching hospital-analysis of trends with assessment of independent predictors in correlation with patient outcomes. Radiology. 2011;258:174-81.

14. Balthazar EJ, Robinson DL, Megibow AJ, Ranson JH. Acute pancreatitis: value of CT in establishing prognosis. Radiology. 1990;174:331-6.

15. Arvanitakis $M$, Delhaye $M$, De Maertelaere V, Bali M, Winant C, Coppens $E_{1}$ et al. Computed tomography and magnetic resonance imaging in the assessment of acute pancreatitis. Gastroenterology. 2004;126:715-23.

16. Brand $M$, Götz $A$, Zeman $F$, Behrens $G$, Leitzmann $M$, Brünnler $T$, et al. Acute necrotizing pancreatitis: laboratory, clinical, and imaging findings as predictors of patient outcome. AJR Am J Roentgenol. 2014;202:1215-31.

17. Pieńkowska J, Gwoździewicz K, Skrobisz-Balandowska K, Marek I, Kostro $J$, Szurowska E, et al. Perfusion-CT--Can We Predict Acute Pancreatitis Outcome within the First 24 Hours from the Onset of Symptoms? PLoS One. 2016;11:e0146965.

18. Munoz-Bongrand $N$, Panis $Y$, Soyer $P$, Riché $F$, Laisné $M J$, Boudiaf $M$, et al. Serial computed tomography is rarely necessary in patients with acute pancreatitis: a prospective study in 102 patients. J Am Coll Surg. 2001;193:146-52. 